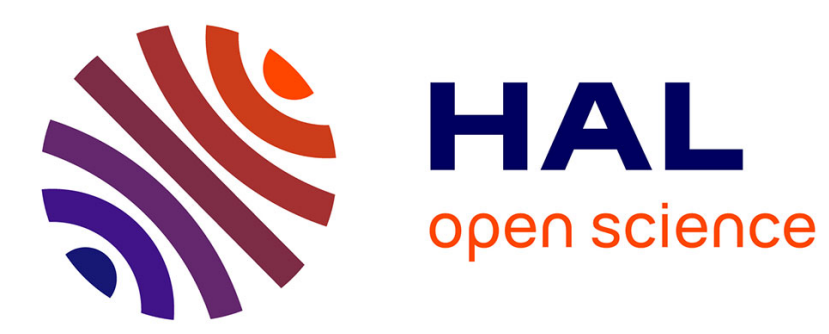

\title{
Steroidogenesis and steroidogenic gene expression in postnatal fetal rat Leydig cells
}

Judith Weisser, Luise Landreh, Olle Söder, Konstantin Svechnikov

\section{To cite this version:}

Judith Weisser, Luise Landreh, Olle Söder, Konstantin Svechnikov. Steroidogenesis and steroidogenic gene expression in postnatal fetal rat Leydig cells. Molecular and Cellular Endocrinology, 2011, 341 (1-2), pp.18. 10.1016/j.mce.2011.03.008 . hal-00719879

\section{HAL Id: hal-00719879 \\ https://hal.science/hal-00719879}

Submitted on 22 Jul 2012

HAL is a multi-disciplinary open access archive for the deposit and dissemination of scientific research documents, whether they are published or not. The documents may come from teaching and research institutions in France or abroad, or from public or private research centers.
L'archive ouverte pluridisciplinaire $\mathbf{H A L}$, est destinée au dépôt et à la diffusion de documents scientifiques de niveau recherche, publiés ou non, émanant des établissements d'enseignement et de recherche français ou étrangers, des laboratoires publics ou privés. 


\section{Accepted Manuscript}

Title: Steroidogenesis and steroidogenic gene expression in postnatal fetal rat Leydig cells

Authors: Judith Weisser, Luise Landreh, Olle Söder, Konstantin Svechnikov<ce:footnote id="fn0005" $><$ ce:note-para $>$ these authors contributed equally

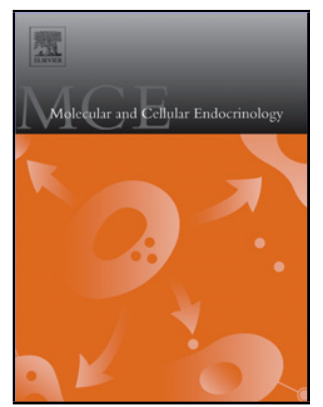
to the work $</$ ce:note-para $><$ ce:footnote $>$

PII:

S0303-7207(11)00167-5

DOI: doi:10.1016/j.mce.2011.03.008

Reference: $\quad$ MCE 7793

To appear in: $\quad$ Molecular and Cellular Endocrinology

Received date: $\quad 24-11-2010$

Revised date: 21-3-2011

Accepted date: $\quad$ 21-3-2011

Please cite this article as: Weisser, J., Landreh, L., Söder, O., Svechnikov, K., Steroidogenesis and steroidogenic gene expression in postnatal fetal rat Leydig cells, Molecular and Cellular Endocrinology (2008), doi:10.1016/j.mce.2011.03.008

This is a PDF file of an unedited manuscript that has been accepted for publication. As a service to our customers we are providing this early version of the manuscript. The manuscript will undergo copyediting, typesetting, and review of the resulting proof before it is published in its final form. Please note that during the production process errors may be discovered which could affect the content, and all legal disclaimers that apply to the journal pertain. 
Short title: steroidogenesis postnatal fetal Leydig cells

\title{
Steroidogenesis and steroidogenic gene expression in postnatal fetal rat Leydig cells
}

\author{
Judith Weisser $^{1}$, Luise Landreh ${ }^{1}$, Olle Söder, Konstantin Svechnikov ${ }^{2}$ \\ Department of Women's and Children's Health, Pediatric Endocrinology Unit Q2:08, Karolinska \\ Institutet \& University Hospital, SE-17176 Stockholm, Sweden
}

\begin{abstract}
Keywords: postnatal fetal Leydig cells, steroidogenesis, steroidogenic gene expression
${ }^{2}$ Correspondence and proofs should be addressed to:

Dr. Konstantin Svechnikov, Department of Women's and Children's Health, Pediatric Endocrinology Unit, Q2:08, Karolinska Institutet and Hospital, Astrid Lindgren Children's Hospital, S-17176 Stockholm, Sweden

Telephone: + 46-8-51772507; fax: +46-8-51775128;

Email: konstantin.svechnikov@ki.se

${ }^{1}$ these authors contributed equally to the work
\end{abstract}

Disclosure statement:The authors have nothing to disclose. 


\begin{abstract}
We studied steroidogenesis and the regulation of Leydig cell-specific gene expression in primary cultures of highly purified postnatal fetal Leydig cells (PFLCs). PFLCs activated by hCG and $(\mathrm{Bu})_{2} \mathrm{cAMP}$ demonstrated transient capacity to produce testosterone $(\mathrm{T})$ in vitro. A time dependent decline in T production by $(\mathrm{Bu})_{2}$ cAMP -stimulated PFLCs was observed and associated with the accumulation of progesterone in the culture media and complete suppression of P450c17 expression at the translational but not transcriptional level. PFLCs was found to lose their capacity to express Leydig cell-related genes (e.g. 3ßHSD, P450c17, Insl3), which was restored by treatment with $(\mathrm{Bu})_{2} \mathrm{CAMP}$. It was also found that PDGF $\alpha$ alone and in combination with $(\mathrm{Bu})_{2} \mathrm{CAMP}$ significantly stimulated proliferation of the isolated PFLCs in vitro. Our data indicate that cAMP-activated signaling pathway(s) play an important role in the regulation of PFLCs differentiation and function.
\end{abstract}

Keywords: postnatal fetal Leydig cells, steroidogenesis, steroidogenic gene expression 


\section{Introduction}

Fetal Leydig cells (FLCs) are a distinct population of Leydig cells that originate in the embryo. These cells secrete androgens that are critical for the normal development of male reproductive organs as well as insulin-like factor 3 (Insl3) required for the abdominal phase of the scrotal descent of the testis (Huhtaniemi and Pelliniemi, 1992; Ivell et al., 1997). In rats, FLCs start to differentiate and produce testosterone at gestational age of 14 days before they undergo functional regression from fetal day 18.5 onward (Habert and Picon, 1984; Kuopio et al., 1989). In humans, the initiation of differentiation of these cells must be independent of $\mathrm{LH}$, since the onset of testicular androgen production precedes the secretion of LH by the pituitary (Habert et al., 2001). This finding strongly support the idea that neither hCG secreted by the placenta nor LH are involved in regulating the initial phase of human fetal Leydig cell differentiation (Habert et al., 2001). However, LH does stimulate testicular testosterone production after the appearance of this hormone and its receptor, indicating that hCG/LH is absolutely required for the maintenance of testicular androgen production at later stages (Rabinovici and Jaffe, 1990). In rodents, fetal Leydig cell function is normal in the absence of LH or its receptor (O'Shaughnessy et al., 1998; Zhang et al., 2001) and LH does not regulate steroidogenic enzyme expression (Majdic et al., 1998).

Desert hedgehog (Dhh) and platelet-derived growth factor A (Pdfga), two Sertoli cell-derived signaling molecules, play an important role in differentiation of fetal Leydig cells (PierucciAlves et al., 2001; Yao et al., 2002; Brennan et al., 2003). Secreted by the Sertoli cell, Dhh acts in a paracrine fashion to induce the differentiation of both the fetal Leydig cells and of the peritubular myoid cells, surrounding the testicular cords (Yao et al., 2002). Dhh activated signaling was suggested to trigger fetal Leydig cell differentiation by up-regulating SF-1 and cytochrome P450 side-chain cleavage (P450scc) expression in precursor cells located outside 
testis cords (Yao et al., 2002). Similarly, mutations in the gene encoding PDGF-A were found to attenuate the expression of P450scc and thereby disrupt early Leydig cell differentiation in mice (Gnessi et al., 2000).

There are several suggestions concerning the fate of FLCs after birth. Postnatal FLCs were found to decrease in number and to disappear from the interstitium probably due to cell death (RoosenRunge and Anderson, 1959), while later reports demonstrated that the total number of FLCs in the testis does not change significantly after birth (Mendis-Handagama et al., 1987; Kuopio et al., 1989). Kuopio et al. (1989) observed an increase in total number of FLCs between postnatal days 3 and 11, a cellular process associated with elevated levels of LH. However, during and after the second postnatal week FLCs showed signs of regression associated with a decreased steroid content per cell (Kuopio et al., 1989). FLCs were shown to persist in the adult testis and do not undergo early postnatal degeneration (Kerr and Knell, 1988). All these findings suggest that postnatal FLCs (PFLCs) may differ from adult Leydig cell lineage in their biology and steroidogenesis.

At present, virtually nothing is known about the function of PFLCs in the neonatal testis. Thus, the aim of this study was to characterize phenotype and steroidogenesis of highly purified PFLCs in vitro. We also investigated the role of cAMP-PKA-dependent signalling in the regulation of the expression of Leydig cell-specific genes in PFLCs and explored paracrine factors controlling their proliferation. 


\section{Material and Methods}

\subsection{Materials}

Dulbeccós Modified Eagle’s Medium (DMEM)-Hams nutrient mixture F-12, Modified Eagle's Medium (MEM), fetal calf serum (FCS), bovine serum albumin (BSA) and antibiotics were obtained from Gibco/BRL (Life Technologies, Paisley, Scotland). Percoll, HEPES, hCG (14000 U/mg), (Bu) $)_{2} \mathrm{cAMP}$ and collagenase type I were purchased from Sigma (Sigma Chemical Co.,

St. Louis, USA). The following antibodies were purchased from Santa Cruz Biotechnology: rabbit polyclonal antiserum against LHR (catalog no. sc-25828); rabbit polyclonal antiserum against Insl3 (catalog no. sc-134587), rabbit polyclonal antiserum against P450c17 (catalog no. sc-66850) and rabbit polyclonal antiserum against WT1 (catalog no. sc-192). Other antibodies were: 3ßHSD (kindly provided by J.I.Mason, University of Edinburg, UK) and StAR (kindly provided by D. Stocco, Texas Tech University, USA).

\subsection{Animals}

Testes from 8-day old Sprague-Dawley rats (B\&K Laboratories, Sollentuna, Sweden and Charles River, Germany) were used for the preparation of PFLCs. These experiments were approved by the Northern Stockholm Animal Ethics Committee (registration no. N319/08).

\subsection{Preparation of testicular cell suspension}

The testes were excised and decapsulated. Testicular tissue was minced using fine scissors and transferred into MEM containing collagenase type I (0,25 mg/ml). Digestion was performed at $37^{0} \mathrm{C}$ for $20 \mathrm{~min}$ in a shaking water bath operating at 100 cycles $/ \mathrm{min}$.

Interstitial cells were separated from tubuli mechanically and filtrated via 70- $\mu$ m nylon mesh. The obtained filtrate was centrifuged at 300xg for 7 minutes and after resuspension in HBSS 
containing $0.1 \%$ BSA the cells were filtrated via $40-\mu \mathrm{m}$ nylon mesh and counted using phasecontrast microscope.

\subsection{Magnetic labeling and isolation of fetal Leydig cells}

Aliquots of cell preparations with a final concentration of $10^{7}$ cells/100 $\mu$ l were labeled using an indirect labeling technique with the magnetic beads attached to a secondary antibody. The separation procedure was carried out according to the manufacturer's instructions (Miltenyi Biotech). In brief, the cells were incubated with polyclonal rabbit anti-LHR IgGs $\left(20 \mu \mathrm{l} / 10^{7}\right.$ cells $)$ for $20 \mathrm{~min}$ at $4^{0} \mathrm{C}$. After two washes the cells were labeled with $30 \mu \mathrm{l} / 10^{7}$ cells goat anti-rabbit IgG microbeads (Miltenyi; order no. 130-048-602) diluted in 70 $\mu \mathrm{l} / 10^{7}$ cells HBSS (containing EDTA and BSA as described above). The cells were incubated for $20 \mathrm{~min}$ at $4^{0} \mathrm{C}$. For the subsequent magnetic separation, ice-cold degassed HBSS buffer containing EDTA and BSA was utilized. The cell suspension was resuspended in degassed buffer (500 $\mu \mathrm{l} / 10^{7}$ cells) and poured into through a MS separation column (Miltenyi: order no. 130-042-201). LHR-positive and thus magnetically labeled cells were retained within the magnetized column matrix, whereas nonlabeled cells passed through and were collected as the nonmagnetic fraction. To increase the purity of the magnetic fraction, the column was washed three times. In order to retrieve the magnetic fraction, the column was removed from the separator and the cells were twice flushed out of the column in $1 \mathrm{ml}$ of degassed buffer. Purified fetal Leydig cells were resuspended in DMEM-F12 supplemented with 365mg/L glutamine, 2\% FCS, $100 \mathrm{IU} / \mathrm{ml}$ penicillin and $100 \mu \mathrm{g} / \mathrm{ml}$ streptomycin. The yield of PFLCs isolated from $2-3 \times 10^{7}$ testicular cells that had been isolated from the testes of 10 pups was $1 \%\left(2-3 \times 10^{5}\right.$ cells, on average 12500 cells per testis). 97$98 \%$ of the cells obtained were $3 \beta \mathrm{HSD}$-positive after immunohistochemical staining for $3 \beta \mathrm{HSD}$ 
(Fig. 1C). To exclude contamination with Sertoli cells, which are abundantly present in the neonatal testis, primary cultures of PFLC were stained for WT1, a marker for Sertoli cells. No expression of WT1 was detected in the primary cultures of PFLC (data not shown). For culturing, $100 \mu \mathrm{l}$ of a suspension containing $1 \times 10^{5}$ cells/ml was plated into each well of a 96well Falcon plate (Falcon, USA) and treated with hCG (10 ng/ml) and $(\mathrm{Bu})_{2} \mathrm{cAMP}(1 \mathrm{mM})$ for different time-points at $34^{0} \mathrm{C}$.

\subsection{Immunohistochemistry}

The immunohistochemical detection of PFLCs was performed as described earlier (Renlund et al., 2006). Cells were cultured for 48 hours on cover glasses placed in 12-well plates followed by fixation with 4\% paraformaldehyde at room temperature for 20 min and permeabilization with 0.3\% Triton X-100 for 5 min. After washing, they were incubated in blocking buffer (10\% donkey serum in PBS and 0.1\% BSA) for 20 min at room temperature followed by incubation with primary rabbit anti-StAR, Insl3, LHR, and 3ßHSD polyclonal antibody at 1:100 dilution for $2 \mathrm{~h}$ at room temperature. The cover slips were then washed 3 times with PBS before incubation with secondary Cy3-conjugated donkey anti-rabbit antibodies (Jackson Immuno Research Lab Inc.) in a dilution of $1: 300$ for $1 \mathrm{~h}$ at $37^{\circ} \mathrm{C}$ and mounted with Vectashield (HardSet, mounting medium with DAPI, Vector lab Inc, Burlingame, CA). The cells were viewed with a Nikon fluorescent microscope (Nikon, Bergstrom Inst., Solna, Sweden). Negative controls were performed using rabbit IgGs in a dilution of 1:100. 


\subsection{Assay of steroidogenic enzymes activity}

Measurement of P450scc, 3ßHSD, P450c17,17 $\beta$ HSD and 17KSR activities was performed by incubating overnight pre-cultured cells $\left(2 \times 10^{4}\right.$ cells/well) with appropriate labeled substrate (e.g., ${ }^{3} \mathrm{H}$-25-OH-cholesterol, ${ }^{3} \mathrm{H}$-pregnenolone, ${ }^{3} \mathrm{H}$-progesterone and ${ }^{3} \mathrm{H}$-androstenedione $\left(10^{5}\right.$ $\mathrm{cpm} /$ well)) and $1 \mu \mathrm{M}$ of corresponding unlabeled steroids for $2 \mathrm{~h}$ at $34^{0} \mathrm{C}$. Control samples of culture medium without cells were incubated and processed in parallel with each enzyme assay and provided blank values that were subtracted from the respective experimental samples. The reaction was stopped by the addition of $5 \mu \mathrm{l} 5 \mathrm{~N} \mathrm{NaOH}$ and the steroids present then extracted once by ice-cold ethyl acetate and organic phases combined and evaporated to complete dryness. The activity of P450scc was determined by measuring the conversion of $25-\left[26,27-{ }^{3} \mathrm{H}\right]$ hydroxycholesterol to pregnenolone (PREGN), progesterone (PROG), 17 $\alpha$-hydroxyprogesterone

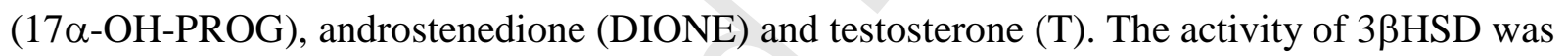
assayed by measuring the conversion of PREGN to PROG, $17 \alpha-\mathrm{OH}-\mathrm{PROG}$, DIONE and T. The activity of P450c17 was determined by measuring conversion of PROG to $17 \alpha-\mathrm{OH}-\mathrm{PROG}$, DIONE and T. The activities of $17 \mathrm{KSR}$ and $17 \beta \mathrm{HSD}$ were assayed by measuring the conversion of DIONE to $\mathrm{T}$ and $\mathrm{T}$ to DIONE, respectively.

The steroids were separated on $60 \mathrm{~F}_{254}$ TLC plates (Merk, Darmstadt, Germany) in chloroformethyl acetate (4:1, v:v) as the mobile phase. The 25-OH-cholesterol, PREGN, PROG, $17 \alpha-\mathrm{OH}-$ PROG, DIONE and T were detected under UV light and by exposure to iodine vapor. The amounts of substrate remaining and products formed were quantified by cutting out the appropriate sections of the silica gel and subjecting these to scintillation counting. 


\subsection{Steroid assays}

Culture medium samples were stored at $-20^{\circ} \mathrm{C}$ prior to analysis of estradiol, testosterone, androstenedione and progesterone. Estradiol, testosterone, androstenedione and progesterone were quantified employing the Coat-a-Count RIA kit (Diagnostic Products Corp., Los Angeles, CA), according to the manufacturer's instructions. Intraassay and interassay coefficients for estradiol, testosterone and androstenedione RIA were 7.0, 6.4, 5.0\% and 7.4, 3.2 and 5.6 \%, respectively. The same parameters for progesterone RIA were 4 and 3.9\%.

\subsection{Isolating RNA and producing cDNA}

Total RNA was extracted from control and $(\mathrm{Bu})_{2}$ cAMP-treated fetal Leydig cells by RNeasy Mini Kit (Qiagen, Hilden, Germany), according to the protocol provided by the manufacturer. The amount of total RNA was measured by photometry (BioPhotometer, Hamburg, Germany). The RNA was kept at $-80^{\circ} \mathrm{C}$ until further analysis.

Total RNA was further processed using iScript cDNA Synthesis Kit (Bio-Rad Laboratories, Hercules, CA) as proposed in the manufacturer's protocol.

\subsection{Gene expression analysis by RT-PCR}

The Expand High Fidelity PCR System (Roche Diagostics, Mannheim, Germany) and dNTP set (GE Healthcare, Germany) were used to prepare the PCR mix (Primer: 0,25 $\mu \mathrm{M}$ each, dNTP: 0,2mM, $\mathrm{MgCl}_{2} 1,5 \mathrm{mM}$, enzyme: $\left.0,9 \mathrm{U}\right)$. The conditions for amplification were $5 \mathrm{~min}$ at $96{ }^{\circ} \mathrm{C}$, followed by $28-35$ cycles of denaturation for $30 \mathrm{~s}$ at $96^{\circ} \mathrm{C}$, annealing for $30-60 \mathrm{~s}$ at $52-58{ }^{\circ} \mathrm{C}$ and extension for $1 \mathrm{~min}$ at $72{ }^{\circ} \mathrm{C}$, and finally extension for $5 \mathrm{~min}$ at $72{ }^{\circ} \mathrm{C}$ and cooling down to 4 ${ }^{\circ} \mathrm{C}$ (Applied Biosystems, 2720 Thermal Cycler). For specific conditions for each gene see Table 
1. Expression of the house-keeping gene $\beta$-actin was also analysed for each testis sample. Primer pairs specific for rat Leydig cell-specific gene cDNAs were designed and then produced by Sigma (Table 1). DNA contamination was excluded by running PCR without reverse transcriptase.

Reaction products were mixed with loading buffer and analysed by electrophoresis through $2 \%$ agarose gel (SeaKem, LE Agarose, Lonza, Rockland,ME) containing gel red (Nucleic Acid Gel Stain, 10000x, Biotium, Hayward, CA). Sample size was controlled by using DNA molecular weight Marker (Roche Diagnostics, Germany). Gels were scanned using a Canon PowerShot A640 and AlphaProView 1.0 software (Alpha Innotech Corporation, San Leandro, CA).

\subsection{Gene expression analysis by $q P C R$}

The samples for qPCR were prepared using iQ SYBR Green Supermix (Bio-Rad Laboratories, Hercules, CA) and the PCR cycles were run at $95{ }^{\circ} \mathrm{C}$ for 10 s, $60{ }^{\circ} \mathrm{C}$ for 45 s, $95{ }^{\circ} \mathrm{C}$ for 60 s and 55 C for 60s followed by a melting curve from $55-95^{\circ} \mathrm{C}$ in steps of $0.5^{\circ} \mathrm{C}$ and then held at $4{ }^{\circ} \mathrm{C}$ (iCycler iQ, Bio-Rad Laboratories, Hercules, CA) after having estimated the best reaction conditions by running a temperature gradient. cDNA samples from 8 day old rats were used as positive control.The gene expression of P450c17 and the house keeping gene $\beta$-actin were analysed using the same primers as for RT-PCR (Table1).

\subsection{Western blot analysis}

The effect of $(\mathrm{Bu})_{2}$ CAMP on the level of expression of cytochrome P450c17 by PFLCs was examined by PAGE/Western blotting as described earlier (Svechnikov et al., 2003; Svechnikov et al., 2005). Briefly, PFLCs stimulated with or without (Bu) 2 CAMP for 4 days were washed 
twice with PBS and then lysed and sonicated in a buffer containing $62.5 \mathrm{mM}$ Tris-Cl (pH 6.8), 2\% SDS, $50 \mathrm{mM}$ dithiothreitol, and 10\% glycerol. Subsequently, the fraction thus solubilised was separated from debris by centrifugation at 10,000xg for $6 \mathrm{~min}$ and the proteins present in the resulting supernatants (30 $\mu$ g protein from each sample) separated by electrophoresis on $10 \%$ SDS/polyacrylamide gels and thereafter transferred electrophoretically to Hybond-P polyvinylidene difluoride (PVDF) membranes (Amersham Pharmacia Biotech, Buckinghamshire, UK), using 25 mM Tris-Cl, 185 mM glycine, pH 8.3, containing 20\% methanol. Polyclonal cytochrome P450c17 antiserum (rabbit polyclonal IgG, Santa Cruz Biotech, USA) was used for incubation at 1:500 in TBS containing 5\% non-fat dry milk overnight at $4{ }^{0} \mathrm{C}$. Antibody against $\beta$-actin (mouse monoclonal IgG, 1:5000; Sigma Chemical Co., St. Louis, USA) was used as an internal standard. After washing, membranes were incubated with donkey anti-rabbit IgG secondary antibodies conjugated with horseradish peroxidase (Amersham Pharmacia Biotech, UK) and the bands detected by incubation with ECL Plus ${ }^{\mathrm{TM}}$ Western blotting agent (Amersham Pharmacia Biotech, UK) and subsequent exposure to Hyperfilm ECL (Amersham Pharmacia Biotech, UK).

\subsection{Assays of PFLCs proliferation}

Isolated cells were cultured for 72 hours with or without $(\mathrm{Bu})_{2} \mathrm{CAMP}, \mathrm{PDGF} \alpha$, LIF and their combinations followed by labelling with ${ }^{3} \mathrm{H}$-thymidine (Amersham Pharmacia Biotech, UK) at concentration of $1 \mu \mathrm{Ci}$ per well for the last 24 hours. The cells were washed and then lysed with $\mathrm{NaOH}(5 \mathrm{~N})$ and incorporated radioactivity was measured in a Beckman liquid scintillation counter. 


\subsection{Statistical analysis}

The differences between various values were analysed for statistical significance by one-way analysis of variance (ANOVA) followed by the Dunnett t-test, using the SigmaStat (v 3.00) package (SPSS, Inc, Chicago, IL). P $<0.05$ was considered to be statistically significant.

\section{Results}

\subsection{Phenotype of postnatal fetal Leydig cells}

Most (97-98\%) of isolated cells were 3ßHSD-positive (Fig. 1C). As shown in Figure 1, PFLCs expressed various Leydig cell-specific proteins such as Insl3 (Fig.1A), LHR (Fig.1B), 3ßHSD (Fig.1C) and StAR (Fig.1D), indicating that this population of Leydig cells was fully differentiated.

\subsection{Basal and hCG-stimulated steroidogenesis in PFLCs}

PFLCs showed low basal production of progesterone and testosterone but their treatment with hCG resulted in a significant (17- and 11-fold , $\mathrm{P}<0.05$, respectively) increase in steroid biosynthesis during first 24 hours of stimulation, a process that was significantly attenuated after prolongation of stimulation with the stimulator for the next 48 hours (Fig.2A,B). This finding indicates that LHR-coated microbeads did not affect LHR-coupled signaling in PFLCs. We also measured the basal activity of steroidogenic enzymes in PFLCs. The order of the activity of the steroidogenic enzymes in PFLCs was found to be 3ßHSD > P450scc > P450c17 > 17KSR>17ßHSD (Fig. 3), suggesting attenuation of progesterone conversion into androstenedione and testosterone. 


\subsection{Time-dependent steroid production by $(\mathrm{Bu})_{2}$ cAMP -activated PFLCs}

We further explored the profile of steroids production by $(\mathrm{Bu})_{2} \mathrm{CAMP}$-activated PFLCs during different time-points of culture. The biosynthesis of testosterone and androstenedione by $(\mathrm{Bu})_{2} \mathrm{cAMP}$-stimulated cells was observed to be maximal after 24 hours of culturing and was then significantly declined in time-dependent manner (Fig 4 A,B). In contrast, $(\mathrm{Bu})_{2} \mathrm{CAMP}$ timedependently activated progesterone production by PFLCs during 72 hours of incubation (Fig. 4C), suggesting that the expression of the cytochrome P450c17 was significantly suppressed in those cells.

\subsection{Effect of long-term stimulation with $(\mathrm{Bu})_{2}$ cAMP on Leydig cell-related gene expression in}

\section{PFLCs}

Since $(\mathrm{Bu})_{2} \mathrm{CAMP}$ is a well-known activator of protein kinase A (PKA) signaling, which upregulates the expression of certain steroidogenic enzymes in adult Leydig cell lineage (Payne and Hales, 2004), we investigated whether treatment with $(\mathrm{Bu})_{2} \mathrm{CAMP}$ influenced the expression of Leydig cell-specific genes in PFLCs. We observed that after 4 days of culturing, PFLCs lost their capacity to express some Leydig cell-derived genes, excluding 17ßHSD (Fig.5). However, treatment with $(\mathrm{Bu})_{2} \mathrm{cAMP}$ up-regulated the expression of all studied Leydig cell-specific genes, excluding LHR, suggesting that cAMP-dependent signaling is required to support PFLCs to stay in a differentiated state. Moreover, we observed that $(\mathrm{Bu})_{2} \mathrm{CAMP}$ slightly but clearly stimulated P450c17 expression, the cellular process associated with accumulation of progesterone in the culture media from PFLCs cells. This apparent contradiction let us to suggest that $(\mathrm{Bu})_{2}$ cAMP up-regulated P450c17 expression at the transcriptional but not translational level. 
To confirm that $(\mathrm{Bu})_{2} \mathrm{CAMP}$ stimulates P450c17 gene expression, a quantitative real-time RTPCR analysis was performed. We demonstrated that treatment with $(\mathrm{Bu})_{2}$ cAMP dramatically (100-fold over control, $\mathrm{P}<0.01$ ) activated the expression of P450c17 (Fig. 6).

\subsection{Effect of $(\mathrm{Bu})_{2} \mathrm{CAMP}$ treatment on P450c17 expression at the protein level}

Indeed, western blot analysis of the P450c17 expression in (Bu) $)_{2}$ CAMP activated PFLCs did not show the cytochrome expression at the protein level, while this steroidogenic enzyme was clearly detected in immature Leydig cells served as positive control (Fig. 7). To test the hypothesis that hCG/(Bu $)_{2}$ CAMP-stimulated PFLC may undergo desensitization via an estradiol-mediated mechanism that suppressed P450c17 function, we measured the levels of estradiol in culture media from same cells activated with $(\mathrm{Bu})_{2} \mathrm{CAMP}$. We observed that $(\mathrm{Bu})_{2} \mathrm{CAMP}$ was not able to stimulate estradiol production by PFLC during 96 hours of stimulation, suggesting lack of activation of aromatase expression in those cells (data not shown).

\subsection{Effect of $(B)_{2}$ cAMP and paracrine factors on PFLC proliferation}

We further explored the role of cAMP-dependent signaling as well as PDGF $\alpha$ and LIF, the paracrine factors that control Leydig cell development (Gnessi et al., 2000; Ge et al., 2006), in the regulation of PFLC proliferation. We observed that PDGF $\alpha$ significantly (1.8-fold over control, $\mathrm{P}<0.05)$ stimulated the proliferation of PFLCs. Similarly, this paracrine factor in combination with $(\mathrm{Bu})_{2} \mathrm{cAMP}$ enhanced markedly the mitotic activity of PFLCs, while $(\mathrm{Bu})_{2} \mathrm{CAMP}$ and LIF alone had no significant effect on PFLC proliferation (Fig.8). 


\section{Discussion}

In the present study we isolated and explored the regulation of steroidogenesis and function of LHR-positive steroidogenic cells from 8-day old neonatal testis designated as PFLCs. Those purified native PFLCs showed a transient (within 24 hours) capacity to produce testosterone in response to exposure to hCG and $(\mathrm{Bu})_{2} \mathrm{cAMP}$ in primary cultures. However, long-term stimulation with $(\mathrm{Bu})_{2} \mathrm{CAMP}$ resulted in accumulation of progesterone in the culture media of PFLCs, suggesting that the function of P450c17 is significantly suppressed in those cells. Further experiments demonstrated that $(\mathrm{Bu})_{2}$ CAMP up-regulated P450c17 gene expression in PFLCs at the transcriptional level but its translation into functional protein was completely suppressed. Our study has also demonstrated that during long-term culturing PFLCs lost their capacity to express the major Leydig cell-related genes (e.g., 3ßHSD, P450c17 and Insl3), the cellular events that were restored by treatment with $(\mathrm{Bu})_{2}$ cAMP. Moreover, we have observed that PDGF $\alpha$ alone and in combination with $(\mathrm{Bu})_{2} \mathrm{CAMP}$ significantly stimulated proliferation of isolated PFLCs in vitro, suggesting that PDGFR $\alpha$-activated signaling play an important role in controlling the mitotic activity of PFLCs and cAMP-PKA-dependent pathway may promote the proliferative effects of PDGFR $\alpha$ on those cells.

It was previously reported that FLCs decline in number after birth, a cellular process suggested to be associated with: (a) cell death (Kuopio et al., 1989), (b) dedifferentiation to fibroblastictype cells (Gondos et al., 1974) or (c) transformation to adult-type Leydig cell population (Mendis-Handagama et al., 1998). However, several studies suggested that PFLCs do not all enter apoptosis and degenerate but can persist in later puberty (Kerr and Knell, 1988; Ariyaratne and Chamindrani Mendis-Handagama, 2000; Ivell et al., 2003). Thus, the fate, function and the regulation of PFLCs after birth are still unknown, while testosterone production by PFLCs 
during neonatal development is thought to require for neonatal masculinization (Ariyaratne and Chamindrani Mendis-Handagama, 2000; Scott et al., 2009).

The present study has demonstrated a role for the cAMP-PKA transduction pathway in the regulation of Leydig-cell specific genes in PFLCs. In the absence of cAMP-activated signaling, PFLCs lost their capacity to express Leydig cell-specific genes such as LHR, 3ßHSD, P450c17 and Insl3 and to produce steroids. However, bypassing stimulation of PFLCs with $(\mathrm{Bu})_{2} \mathrm{cAMP}$ beyond LHR supported the expression of 3ßHSD, P450c17 and Insl3 but not LHR, indicating that the persistent activation of cAMP-dependent signaling is a requisite condition for supporting steroidogenic gene expression in PFLCs. This observation agrees well with the earlier studies demonstrated that the cAMP-PKA transduction pathway plays an important role in supporting expression and function of 3ßHSD and P450c17 in mouse Leydig cells (Anakwe and Payne, 1987; Keeney and Mason, 1992). Moreover, our data support the idea that expression of P450c17 is highly dependent on cAMP stimulation not only in adult Leydig cells but also in fetal Leydig cells (Scott et al., 2009). However, the present study demonstrated that stimulation of PFLCs with $(\mathrm{Bu})_{2}$ CAMP up-regulates P450c17 gene expression at the transcriptional but not translational level. The lack of functional protein was reflected by an accumulation of progesterone in the culture medium. The mechanism behind this observation is not clear but appears not to be associated with desensitization induced by overstimulation with hCG/(Bu $)_{2}$ CAMP, a cellular event associated with suppression of P450c17 expression in adult Leydig cells via an estrogen-dependent mechanism (Tsai-Morris et al., 1985). A previous study has demonstrated that the inability of the FLC to be desensitized by LH/hCG treatment was associated with low levels of aromatase activity and undetectable estradiol production (Tsai- 
Morris et al., 1986). This observation is in line with our finding showing lack of estradiol production by cultures of PFLCs stimulated with $(\mathrm{Bu})_{2} \mathrm{CAMP}$, suggesting that aromatase expression is not regulated by cAMP-dependent signaling pathway(s) in those cells. Our finding that PFLCs express Insl3, a factor of importance for the first phase of testicular descent (Ivell et al., 1997) is agreed well with previous studies demonstrating high levels of Insl 3 expression in FLCs (Balvers et al., 1998; McKinnell et al., 2005). We demonstrated that PFLCs lost their capacity to express Insl3 after long-term culturing and that $(\mathrm{Bu})_{2} \mathrm{CAMP}$ prevented this down-regulation, indicating that Insl3 gene expression in PFLCs might be controlled by cAMP-dependent signaling pathway(s). We hypothesize that under basal unstimulated conditions in vitro PFLCs undergo dedifferentiation, a process accompanied by significant attenuation and/or cessation of the expression of key Leydig cell-derived genes including Insl3. These findings are supported by several studies in which dedifferentiation of the Leydig cells from the testis of short-day exposed hamsters was associated with losing their steroidogenic capacity (Lerchl et al., 1993) and ability to express Insl3 (Ivell et al., 2003). Moreover, the expression of Insl3 was found to be markedly reduced in dedifferentiated hyperplastic or neoplastic human Leydig cells (Klonisch et al., 1999). However, our present in vitro observations on purified native PFLCs need to be verified under in vivo conditions. The present study also demonstrated a role of PDGF $\alpha$ for the regulation of PFLC proliferation. We have found that PDGF $\alpha$ alone and in combination with $(\mathrm{Bu})_{2} \mathrm{CAMP}$ significantly stimulated proliferation of PFLCs, suggesting that the cAMP-PKA-dependent pathway and PDGFR $\alpha$-activated signaling may converge and influence the same target proteins that control mitotic activity of PFLCs. An important role of PDGF $\alpha$ in controlling FLCs development was demonstrated in recent studies, showing that PDGF $\alpha$-dependent signaling acts in fetal Leydig 
cells (Schmahl et al., 2008) and PDGFR $\alpha$ null males have reduced or absent fetal Leydig cells due to attenuated proliferation of SF-1 positive precursor fetal Leydig cells (Brennan et al., 2003).

In summary, the present study show for the first time that purified native PFLCs possess a transient capacity to produce testosterone due to attenuation of P450c17 translation into the functional protein. Long-term culturing of PFLCs induces a significant suppression of the expression of a number of Leydig cell-derived genes (e.g., 3ßHSD, P450c17 and Insl3), a process that was rescued by $(\mathrm{Bu})_{2} \mathrm{CAMP}$. These findings indicate that cAMP-dependent signaling may play an important role in supporting PFLC differentiation and function. Moreover, the present study demonstrated that PDGF $\alpha$ and cAMP-PKA signaling operate in concert to stimulate the proliferation of PFLCs. Taken together, the present results may contribute to better understanding of mechanism(s) behind disorders of sex development including cryptorchidism in boys.

\section{Acknowledgements}

The present study was supported financially by grants from the Swedish Research Council (No. 8282), the Swedish Children's Cancer Fund, the Frimurare Barnhuset Foundation in Stockholm, Sällskapet Barnavård, Stiftelsen Samariten and Karolinska Institute.

We wish to thank Dr. Blesson Selvanesan and Britt Masironi for technical support with the qPCR. 


\section{References}

Anakwe, O.O., Payne, A.H., 1987. Noncoordinate regulation of de novo synthesis of cytochrome P-450 cholesterol side-chain cleavage and cytochrome P-450 17 alphahydroxylase/C17-20 lyase in mouse Leydig cell cultures: relation to steroid production. Mol Endocrinol 1, 595-603.

Ariyaratne, H.B., Chamindrani Mendis-Handagama, S., 2000. Changes in the testis interstitium of Sprague Dawley rats from birth to sexual maturity. Biol Reprod 62, 680-690.

Balvers, M., Spiess, A.N., Domagalski, R., Hunt, N., Kilic, E., Mukhopadhyay, A.K., Hanks, E., Charlton, H.M., Ivell, R., 1998. Relaxin-like factor expression as a marker of differentiation in the mouse testis and ovary. Endocrinology 139, 2960-2970.

Brennan, J., Tilmann, C., Capel, B., 2003. Pdgfr-alpha mediates testis cord organization and fetal Leydig cell development in the XY gonad. Genes Dev 17, 800-810.

Ge, R.S., Dong, Q., Sottas, C.M., Papadopoulos, V., Zirkin, B.R., Hardy, M.P., 2006. In search of rat stem Leydig cells: identification, isolation, and lineage-specific development. Proc Natl Acad Sci U S A 103, 2719-2724.

Gnessi, L., Basciani, S., Mariani, S., Arizzi, M., Spera, G., Wang, C., Bondjers, C., Karlsson, L., Betsholtz, C., 2000. Leydig cell loss and spermatogenic arrest in platelet-derived growth factor (PDGF)-A-deficient mice. J Cell Biol 149, 1019-1026.

Gondos, B., Paup, D.C., Ross, J., Gorski, R.A., 1974. Ultrastructural differentiation of Leydig cells in the fetal and postnatal hamster testis. Anat Rec 178, 551-565.

Habert, R., Lejeune, H., Saez, J.M., 2001. Origin, differentiation and regulation of fetal and adult Leydig cells. Mol Cell Endocrinol 179, 47-74. 
Habert, R., Picon, R., 1984. Testosterone, dihydrotestosterone and estradiol-17 beta levels in maternal and fetal plasma and in fetal testes in the rat. J Steroid Biochem 21, 193-198.

Huhtaniemi, I., Pelliniemi, L.J., 1992. Fetal Leydig cells: cellular origin, morphology, life span, and special functional features. Proc Soc Exp Biol Med 201, 125-140.

Ivell, R., Balvers, M., Anand, R.J., Paust, H.J., McKinnell, C., Sharpe, R., 2003. Differentiationdependent expression of 17beta-hydroxysteroid dehydrogenase, type 10, in the rodent testis: effect of aging in Leydig cells. Endocrinology 144, 3130-3137.

Ivell, R., Balvers, M., Domagalski, R., Ungefroren, H., Hunt, N., Schulze, W., 1997. Relaxinlike factor: a highly specific and constitutive new marker for Leydig cells in the human testis. Mol Hum Reprod 3, 459-466.

Keeney, D.S., Mason, J.I., 1992. Expression of testicular 3 beta-hydroxysteroid dehydrogenase/delta 5----4-isomerase: regulation by luteinizing hormone and forskolin in Leydig cells of adult rats. Endocrinology 130, 2007-2015.

Kerr, J.B., Knell, C.M., 1988. The fate of fetal Leydig cells during the development of the fetal and postnatal rat testis. Development 103, 535-544.

Klonisch, T., Ivell, R., Balvers, M., Kliesch, S., Fischer, B., Bergmann, M., Steger, K., 1999. Expression of relaxin-like factor is down-regulated in human testicular Leydig cell neoplasia. Mol Hum Reprod 5, 104-108.

Kuopio, T., Tapanainen, J., Pelliniemi, L.J., Huhtaniemi, I., 1989. Developmental stages of fetaltype Leydig cells in prepubertal rats. Development 107, 213-220.

Majdic, G., Saunders, P.T., Teerds, K.J., 1998. Immunoexpression of the steroidogenic enzymes 3-beta hydroxysteroid dehydrogenase and 17 alpha-hydroxylase, C17,20 lyase and the receptor 
for luteinizing hormone $(\mathrm{LH})$ in the fetal rat testis suggests that the onset of Leydig cell steroid production is independent of LH action. Biol Reprod 58, 520-525.

McKinnell, C., Sharpe, R.M., Mahood, K., Hallmark, N., Scott, H., Ivell, R., Staub, C., Jegou, B., Haag, F., Koch-Nolte, F., Hartung, S., 2005. Expression of insulin-like factor 3 protein in the rat testis during fetal and postnatal development and in relation to cryptorchidism induced by in utero exposure to di (n-Butyl) phthalate. Endocrinology 146, 4536-4544.

Mendis-Handagama, S.M., Ariyaratne, H.B., Teunissen van Manen, K.R., Haupt, R.L., 1998. Differentiation of adult Leydig cells in the neonatal rat testis is arrested by hypothyroidism. Biol Reprod 59, 351-357.

Mendis-Handagama, S.M., Risbridger, G.P., de Kretser, D.M., 1987. Morphometric analysis of the components of the neonatal and the adult rat testis interstitium. Int J Androl 10, 525-534. O'Shaughnessy, P.J., Baker, P., Sohnius, U., Haavisto, A.M., Charlton, H.M., Huhtaniemi, I., 1998. Fetal development of Leydig cell activity in the mouse is independent of pituitary gonadotroph function. Endocrinology 139, 1141-1146.

Payne, A.H., Hales, D.B., 2004. Overview of steroidogenic enzymes in the pathway from cholesterol to active steroid hormones. Endocr Rev 25, 947-970.

Pierucci-Alves, F., Clark, A.M., Russell, L.D., 2001. A developmental study of the Desert hedgehog-null mouse testis. Biol Reprod 65, 1392-1402.

Rabinovici, J., Jaffe, R.B., 1990. Development and regulation of growth and differentiated function in human and subhuman primate fetal gonads. Endocr Rev 11, 532-557.

Renlund, N., Jo, Y., Svechnikova, I., Holst, M., Stocco, D.M., Soder, O., Svechnikov, K., 2006. Induction of steroidogenesis in immature rat Leydig cells by interleukin-1alpha is dependent on extracellular signal-regulated kinases. J Mol Endocrinol 36, 327-336. 
Roosen-Runge, E.C., Anderson, D., 1959. The development of the interstitial cells in the testis of the albino rat. Acta Anat (Basel) 37, 125-137.

Schmahl, J., Rizzolo, K., Soriano, P., 2008. The PDGF signaling pathway controls multiple steroid-producing lineages. Genes Dev 22, 3255-3267.

Scott, H.M., Mason, J.I., Sharpe, R.M., 2009. Steroidogenesis in the fetal testis and its susceptibility to disruption by exogenous compounds. Endocr Rev 30, 883-925.

Svechnikov, K., Stocco, D.M., Söder, O., 2003. Interleukin-1alpha stimulates steroidogenic acute regulatory protein expression via p38 MAP kinase in immature rat Leydig cells. J Mol Endocrinol 30, 59-67.

Svechnikov, K., Supornsilchai, V., Strand, M.L., Wahlgren, A., Seidlova-Wuttke, D., Wuttke, W., Soder, O., 2005. Influence of long-term dietary administration of procymidone, a fungicide with anti-androgenic effects, or the phytoestrogen genistein to rats on the pituitary-gonadal axis and Leydig cell steroidogenesis. J Endocrinol 187, 117-124.

Tsai-Morris, C.H., Aquilano, D.R., Dufau, M.L., 1985. Gonadotropic regulation of aromatase activity in the adult rat testis. Endocrinology 116, 31-37.

Tsai-Morris, C.H., Knox, G., Luna, S., Dufau, M.L., 1986. Acquisition of estradiol-mediated regulatory mechanism of steroidogenesis in cultured fetal rat Leydig cells. J Biol Chem 261, 3471-3474.

Yao, H.H., Whoriskey, W., Capel, B., 2002. Desert Hedgehog/Patched 1 signaling specifies fetal Leydig cell fate in testis organogenesis. Genes Dev 16, 1433-1440.

Zhang, F.P., Poutanen, M., Wilbertz, J., Huhtaniemi, I., 2001. Normal prenatal but arrested postnatal sexual development of luteinizing hormone receptor knockout (LuRKO) mice. Mol Endocrinol 15, 172-183. 


\section{Figure Legends}

Table 1. Primer sequences and PCR conditions for Leydig cell-specific genes

Fig.1 Expression of Leydig cell specific proteins by PFLCs. PFLCs positively stained for Insl3 (A), LHR (B), 3ßHSD (C) and StAR (D). Negative controls for the corresponding proteins are also showed (E-H).

Fig.2 Time-dependent changes in testosterone (A) and progesterone (B) production by hCG (10ng/ml)- stimulated PFLCs and unstimulated cells. Purified PFLCs were incubated with or without hCG (10 ng/ml) for 24, 48 and $72 \mathrm{~h}$. Testosterone and progesterone in the culture medium were then measured by RIA and the results expressed as ng $/ 10^{5}$ cells per $24 \mathrm{~h}$. Mean values \pm SE for three independent PFLCs preparations are presented. ${ }^{*} \mathrm{p}<0,05$ compared to unstimulated control.

Fig.3 Levels of steroidogenic enzyme activities in PFLCs. Cells were cultured overnight and the enzyme activities measured as described in Materials and Methods. Mean values \pm SE for three independent PFLCs preparations are presented.

Fig.4 The profile of steroids production by $(\mathrm{Bu})_{2} \mathrm{CAMP}$-activated PFLCs during different time-points of culture. Purified PFLCs were incubated with or without $(\mathrm{Bu})_{2} \mathrm{cAMP}(1 \mathrm{mM})$ for 24, 48, 72 and 96h. Testosterone (Fig.4A), androstenedione (Fig.4B) and progesterone (Fig.4C) in the culture medium were then measured by RIA and the results expressed as ng/10 ${ }^{5}$ cells per $24 \mathrm{~h}$. Mean values \pm SE for four independent PFLCs preparations are presented. ${ }^{*} \mathrm{p}<0,05 ;{ }^{* * *} \mathrm{p}<0,001$ compared to unstimulated control. 
Fig.5 Effect of $(\mathrm{Bu})_{2}$ CAMP on the expression of Leydig cell-derived genes in PFLCs. Cells were cultured with or without $(\mathrm{Bu})_{2}$ CAMP for 4 days, followed by investigation of gene expression by RT-PCR as described in Materials and Methods. Each experiment was repeated twice with the similar result.

\section{Fig. 6}

Effect of $(\mathrm{Bu})_{2} \mathrm{CAMP}$ treatment on the expression of P450c17 mRNA in PFLCs. Cells were treated with or without $(\mathrm{Bu})_{2}$ CAMP for 4 days, followed by quantitative real-time RT-PCR analysis as described in Materials and Methods. P450c17 mRNA levels were determinate by quantitative real-time RT-PCR using $\beta$-actin as housekeeping gene. Each experiment was performed independently three times with similar results. ${ }^{* *} \mathrm{p}<0,01$ compared with unstimulated control.

\section{Fig. 7}

Effect of $(\mathrm{Bu})_{2}$ cAMP treatment on the level of P450c17 expression in PFLCs. The cultures of PFLCs were treated with or without $(\mathrm{Bu})_{2}$ CAMP for 4 days. Thereafter, the cells were lysed and the level of P450c17 in aliquots of these whole cell lysates (30 $\mu \mathrm{g} /$ protein) analyzed by PAGE/Western blotting as described in Materials and Methods. PC-positive control (protein extract from 40-day old Leydig cells). Each experiment was repeated twice with the similar result.

Fig.8 Effect of paracrine factors and activators of steroidogenesis on proliferation of PFLCs. Cells were cultured with or without LIF, PDGF $\alpha$ and $(\mathrm{Bu})_{2} \mathrm{CAMP}$ for 72 hours and labeled with ${ }^{3} \mathrm{H}$-thymidine for $24 \mathrm{~h}$, followed by cell lysis. Incorporated radioactivity was determined as described in Materials and Methods. Data were expressed as incorporation of ${ }^{3} \mathrm{H}-$ 
thymidine per number of cells during the last $24 \mathrm{~h}$ of culture. Each experiment was performed independently three times with similar results. ${ }^{*} \mathrm{p}<0,05$ compared with unstimulated control. 


\begin{tabular}{|c|c|c|c|}
\hline Name & Sequence & Size & $\begin{array}{l}\text { Cycles; annealing } \\
\text { temperature }\end{array}$ \\
\hline LHR & $\begin{array}{l}\text { 5’-CTGCGCCTTCAGGAATTTGCC-3’ } \\
\text { 5'-AATCATAATCCCAGCCACTGAGTTCATTCT-3' }\end{array}$ & 161bp & $30,56^{\circ} \mathrm{C}$ \\
\hline Insl3 & $\begin{array}{l}\text { 5’-ACGCAGCCTGTGGACACC-3’' } \\
\text { 5'-CAATCCGGGGGTGTTTCATT-3' }\end{array}$ & 313bp & $28,58^{\circ} \mathrm{C}$ \\
\hline $3 \beta-H S D$ & $\begin{array}{l}\text { 5'-ATGCCCAGTACCTGAGGAGA-3' } \\
\text { 5'-TTGAGGGCCGCAAGTATCA-3' }\end{array}$ & 427bp & $30,58^{\circ} \mathrm{C}$ \\
\hline P450c17 & $\begin{array}{l}\text { 5’-ACCTAGAGGCCACAACTAACATCC-3’ } \\
\text { 5’-GAGGCACTGGGACTAGCACCT-3’ }\end{array}$ & 80bp & $28,54^{\circ} \mathrm{C}$ \\
\hline $17 \beta$-HSD & $\begin{array}{l}\text { 5'-AATGTGCTTTCCATTTGCAAGGT-3’ } \\
\text { 5'-ATGCCACTGGCAGAGGAGATG-3' }\end{array}$ & $\begin{array}{l}80- \\
150 b p\end{array}$ & $30,56^{\circ} \mathrm{C}$ \\
\hline$\beta$-actin & $\begin{array}{l}\text { 5’- TGAAGATCAAGATCATTGCTCC-3’ } \\
\text { 5’-ACTCATCGTACTCCTGCTTGC-3' }\end{array}$ & 120bp & $30,56^{\circ} \mathrm{C}$ \\
\hline
\end{tabular}




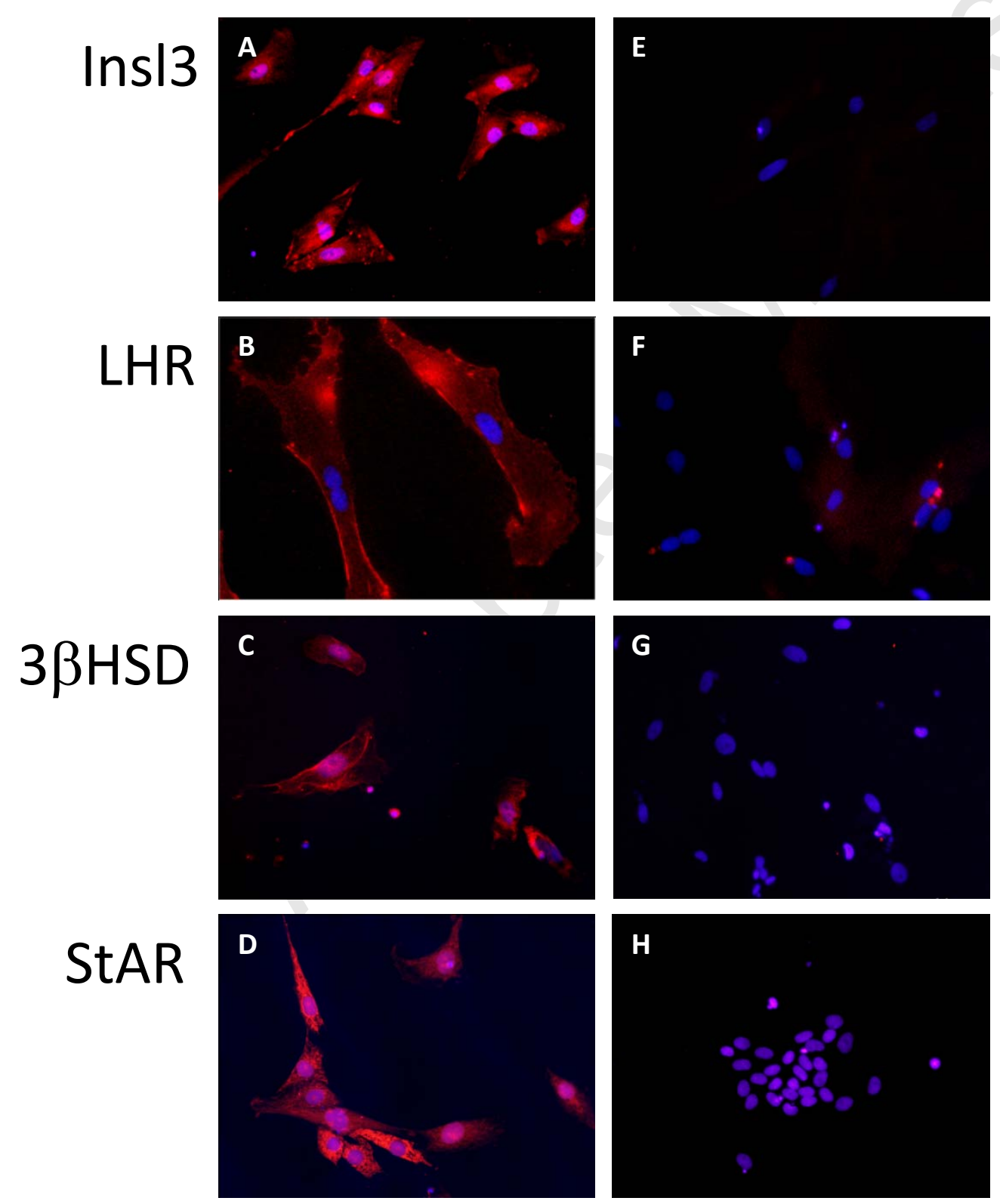

Fig 1 
Fig 2

A

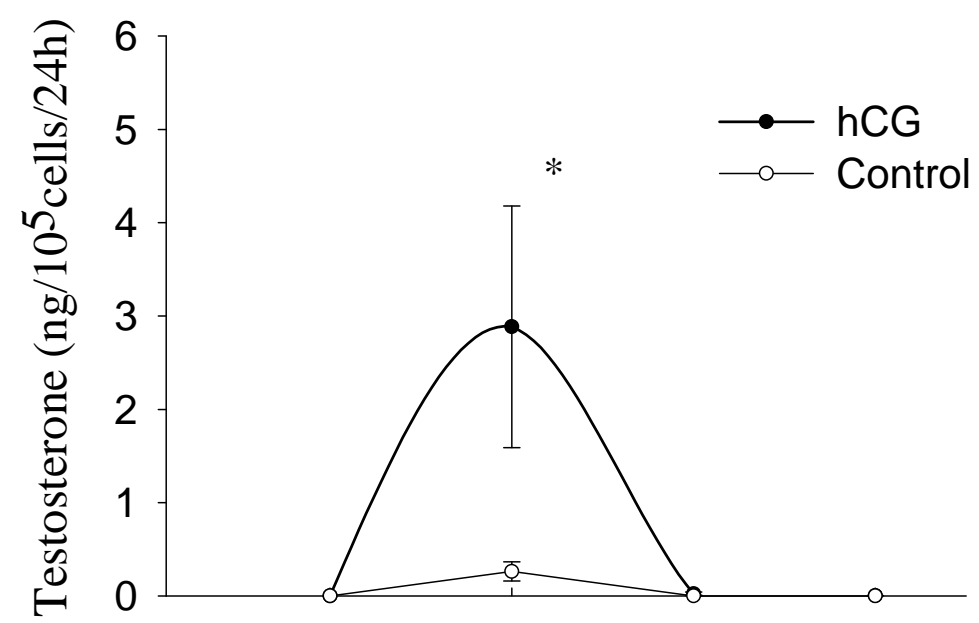

B

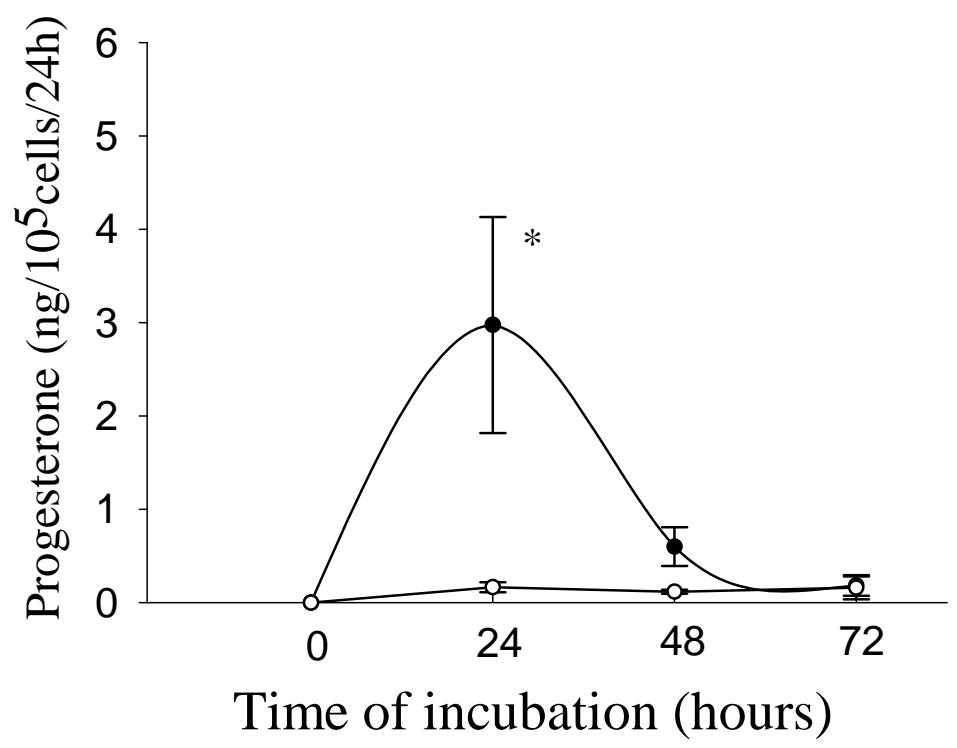


Fig 3

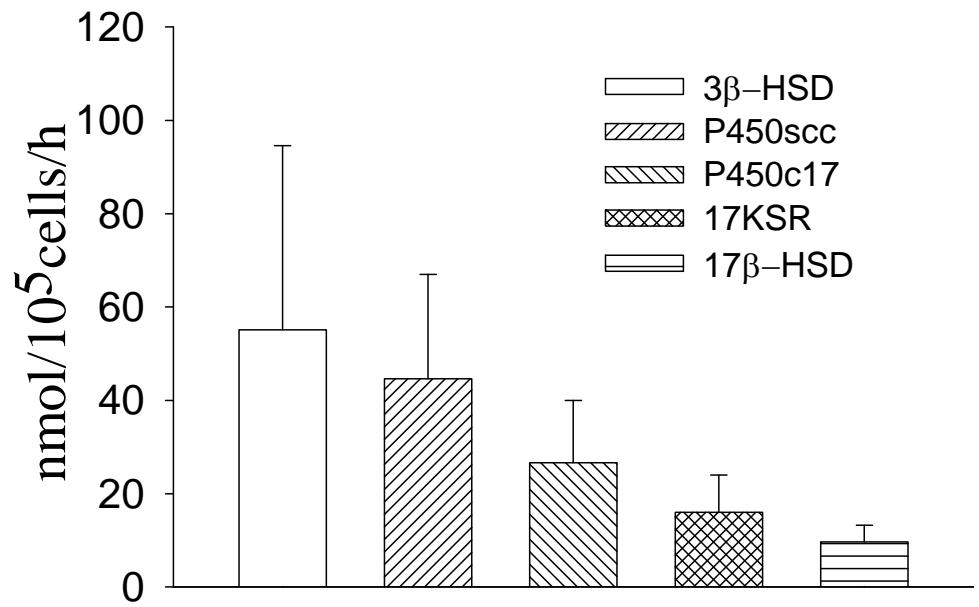


Fig 4

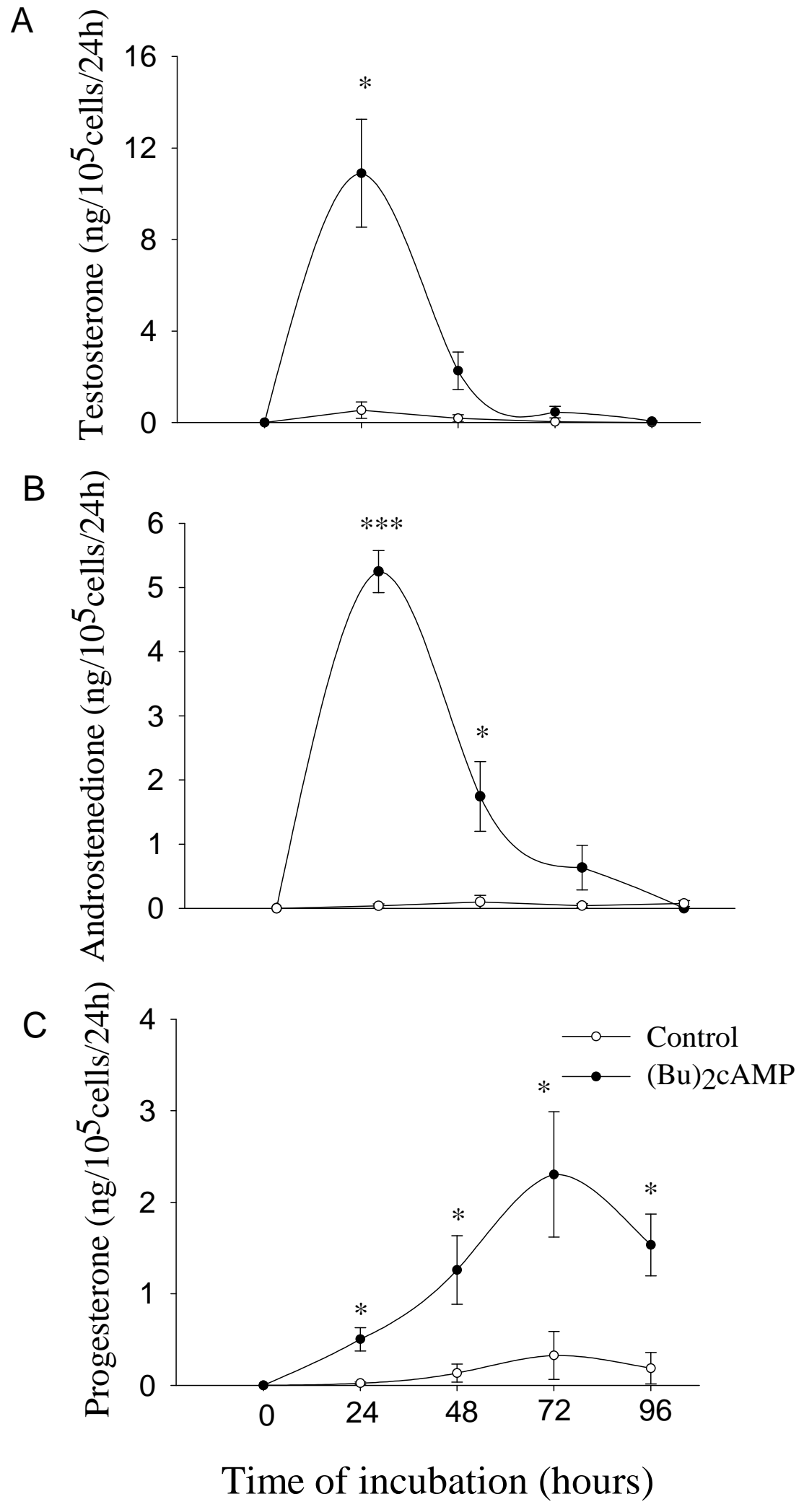




\section{Fig 5}

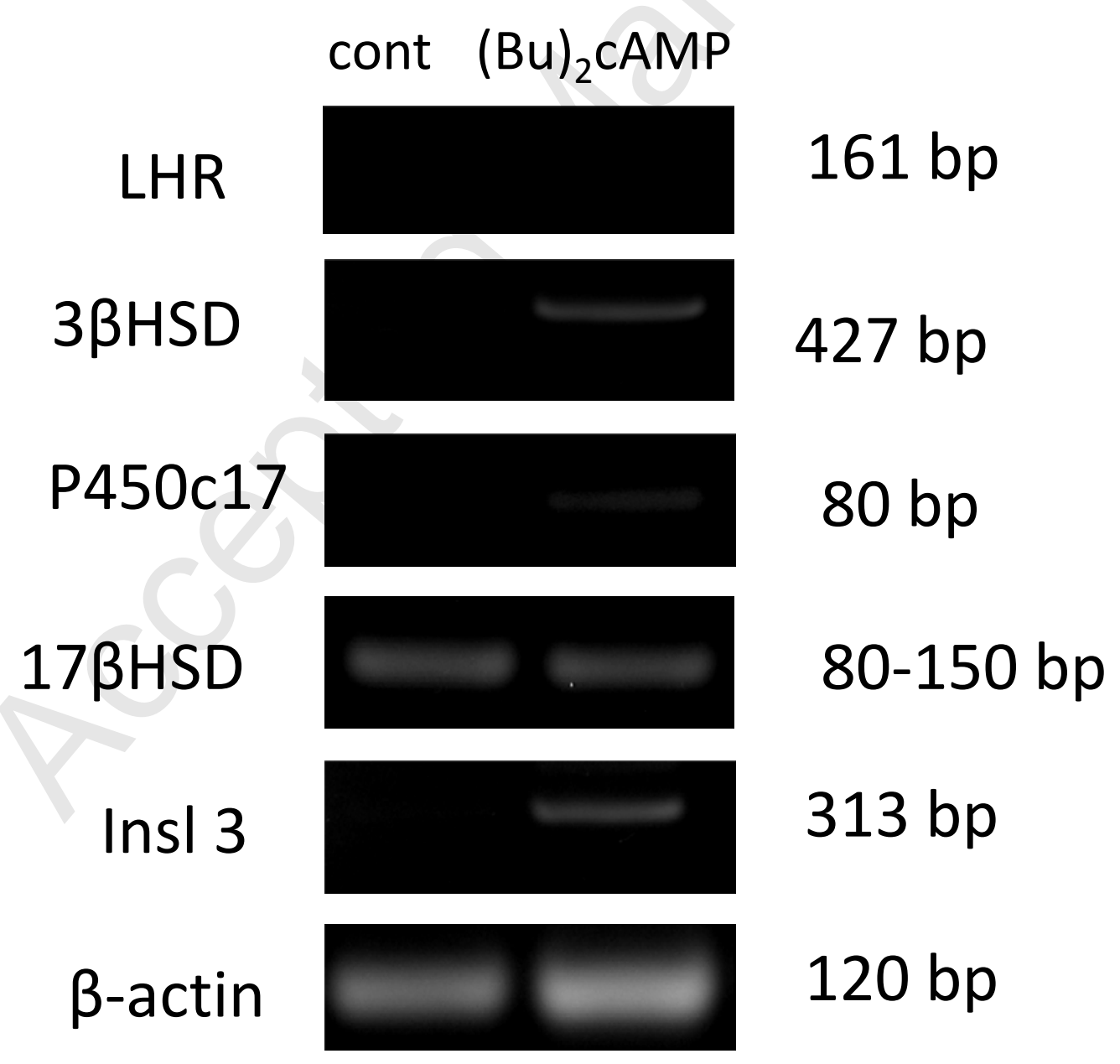


Fig 6

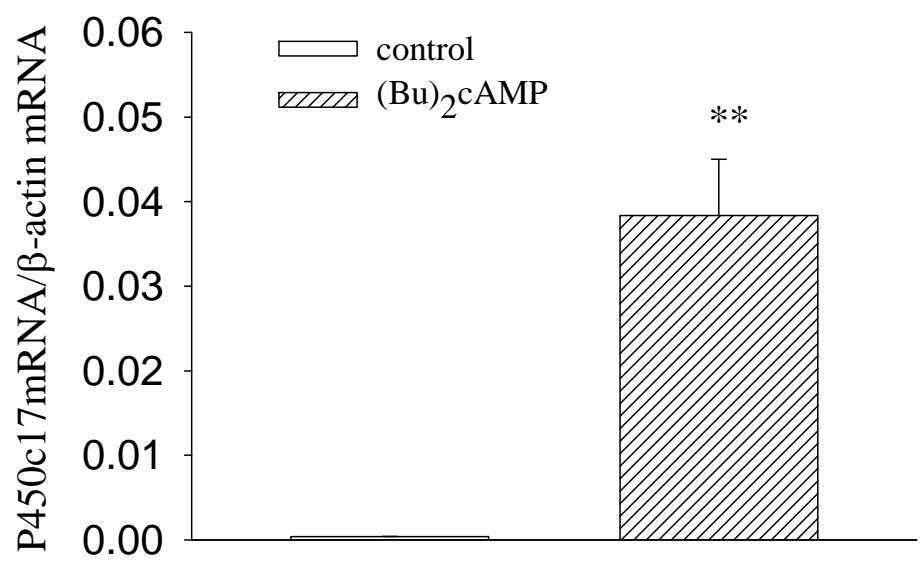




\section{Fig 7}

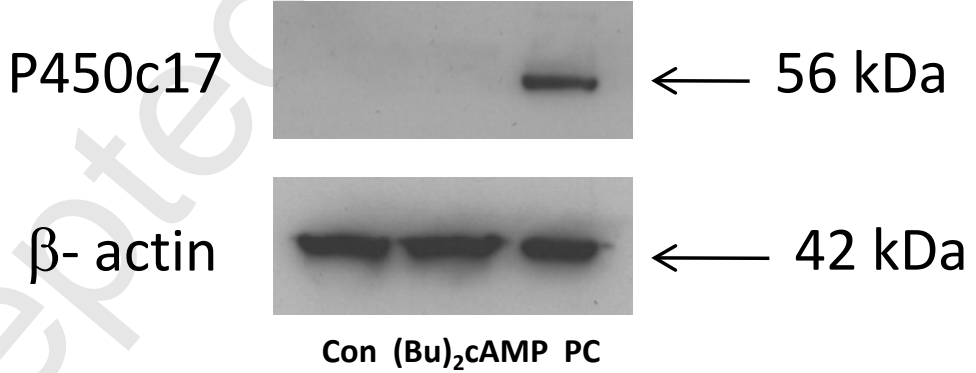


Fig 8

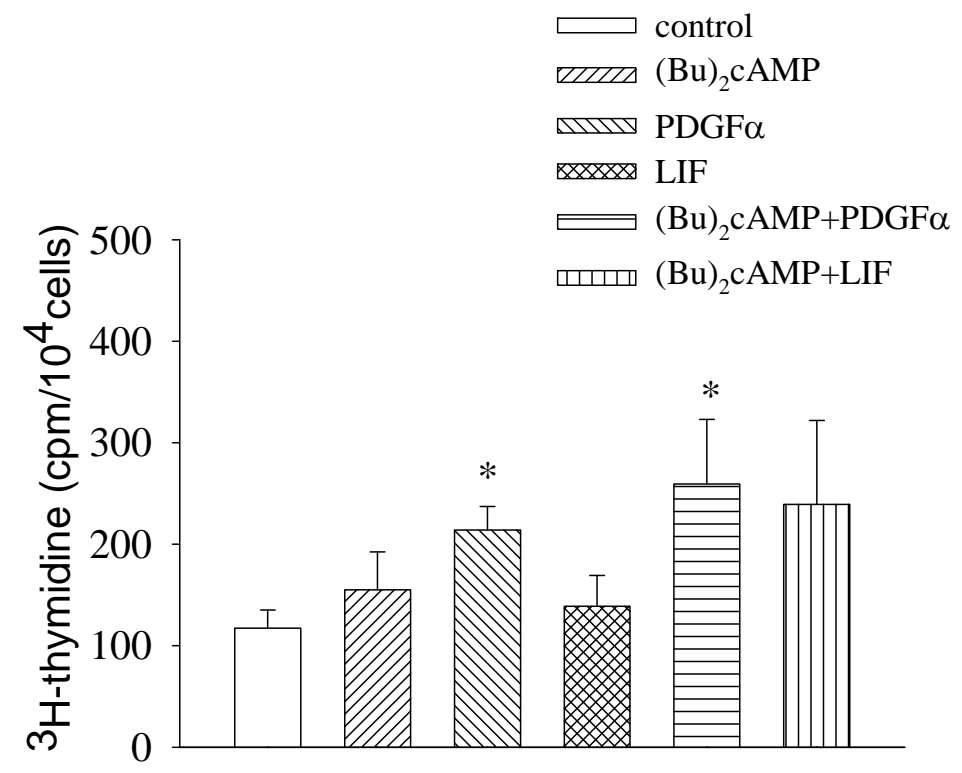

